\title{
Trusler, tilskyndelse - eller "bare" hadtale? Placering af agenten i udsagn om fremtidig skade
}

\section{Tanya Karoli Christensen}

\begin{abstract}
Hadtale er et samfundsproblem som rettelig tiltrækker sig opmærksomhed fra både politikere, medier og forskning. I flere definitioner af hadtale indgår trusler og tilskyndelse til vold mod offergruppen som to af mange former hadtale kan tage. Begge indebærer omtale af en fremtidig handling der vil være skadelig for offeret, men de adskiller sig ved hvem der præsenteres som ansvarlig for skadeshandlingen: afsender eller andre. I denne artikel undersøger jeg eksempler på dansksproget hadtale som omtaler fremtidig skade mod nogen, med særligt henblik på hvordan agenten realiseres, skjules eller placeres hos andre end afsender. Artiklen afsluttes med en diskussion af ytringsfrihed i forhold til kriminelle sproghandlinger.
\end{abstract}

\section{Nøgleord}

retslingvistik, kriminelle sproghandlinger, agentrollen, grammatiske konstruktioner

\section{Baggrund: Retslingvistik og kriminelle sproghand- linger}

Retslingvistikken interesserer sig blandt meget andet for sprogbrug der indgår i kriminelle sammenhænge (se fx Shuy 1993; Coulthard, Johnson \& Wright 2017; Leonard, Ford \& Christensen 2017). Et af de grundlæggende spørgsmål i den forbindelse er hvilke former for sproghandlinger der kriminaliseres af lovgivningen, og hvad der skal til for at der på den måde er foretaget en forbrydelse med sproget (se om begrebet 'sprogfor- 
brydelser' hos Shuy 1993; Solan \& Tiersma 2005; og begrebet 'kriminelle sproghandlinger' hos Christensen 2019).

Denne artikel beskæftiger sig med den sproglige kodning af visse sproghandlinger der potentielt er kriminelle, nemlig dem der tilkendegiver en intention eller et ønske om at der skal ske en fremtidig skade mod et andet menneske eller en gruppe af mennesker. Sådanne ytringer kan fx tage form af trusler som i $(1)^{1}$.

(1) Jesper Bang din lille svans, jeg gennemtæsker dit ansigt

Trusler er kriminaliseret i den danske straffelovs $§ 266$ (se afsnit 2). Karakteristisk for truslen som sproghandling er det at afsender tager eksplicit eller implicit ansvar for udførelsen af den skadelige handling (se fx Fraser 1998: 161; Salgoeiro 2010: 216-217; Muschalik 2018: 79-80; Christensen \& Bojsen-Møller 2019: 213). Det kan helt prototypisk ske ved at præsentere afsender som agent, som i (1). Men også når afsender ikke fremstiller sig selv som medansvarlig, kan der være tale om en kriminel sproghandling. I dansk straffelov kriminaliserer tilskyndelsesparagraffen (§ 136) det at tilskynde andre til at udføre forbrydelser af en vis grovhed, herunder grov vold og drab (se afsnit 2 og 6).

I denne artikel undersøger jeg den grammatiske kodning af agenten for en fremtidig skadeshandling mod et offer i online hadtale ${ }^{2}$. Hadtale er et overbegreb for mange forskellige måder at kommunikere på, som bl.a. omfatter sproghandlingerne trussel og tilskyndelse til vold (se afsnit 2). Datamaterialet for undersøgelsen stammer fra den frivillige organisation Center for Forebyggelse af Eksklusion som gennem en årrække har indsamlet eksempler på hadtale (se afsnit 3). Blandt disse eksempler fokuserer jeg altså her på ytringer der omtaler eller antyder en fremtidig skade mod nogen, som $\mathrm{fx}$ leksikaliseret i prædikater som skyde og brende ned (se afsnit 4). Dette fokus skyldes min nuværende forskning under det Carlsbergfond-finansierede projekt

1 Medmindre andet noteres, er alle eksempler i denne artikel autentiske og stammer fra det datasæt der beskrives i afsnit 3. Alle personnavne er ændret til pseudonymer.

2 Jeg følger Hansen \& Heltoft (2011: 1392-1405) i at lade de grammatiske konstruktioner være den første faktor i bestemmelsen af hvilken semantisk rolle de syntaktiske led tilskrives. Eftersom subjektet i dansk syntaktisk set er neutralt for semantisk rolle, må man dernæst inddrage verbets leksikalske indhold samt den pragmatiske kontekst for at kunne afgøre om subjektet fx er agent som er "den hyppigste faktiske udfyldning" i transitivkonstruktioner (Hansen og Heltoft 2011: 1400). 
Truslers sprog og genre ${ }^{3}$. Materialet fra Center for Forebyggelse af Eksklusion indeholder dog kun et fåtal egentlige trusler (hvor afsender fremstilles som agent), men til gengæld anvendes en række grammatiske konstruktioner der enten skjuler hvem agenten er, eller placerer agentrollen hos andre (se afsnit 5). Det er især de sidste der kan betragtes som tilskyndelser (se afsnit 6). Selv hvis ytringerne bare som holdnings- og følelsesudsagn, er det en pointe for en del forskning i hadtale at den vedvarende nedgørelse og dehumanisering af visse grupper i samfundet kan motivere enkeltindivider eller grupperinger til fysisk vold (se fx Posselt 2017; Müller \& Schwarz 2019a, 2019b). Det vender jeg tilbage til i diskussionen (afsnit 7).

\title{
2. Hadtale, trusler og tilskyndelse
}

Som allerede antydet er hadtale, trusler og tilskyndelse metasproglige termer der befinder sig på forskellige taksonomiske niveauer. Hadtale kan således ses som et overbegreb for mange forskellige former for ytringer, jf. definitionen i det danske Institut for Menneskerettigheders rapport om Hadefulde ytringer $i$ den offentlige debat:

\begin{abstract}
"Stigmatiserende, nedsættende, krænkende, chikanerende og truende ytringer, der fremsættes offentligt mod et individ eller en gruppe baseret på individets eller gruppens køn, etnicitet, religion, handicap, seksuelle orientering, alder, politiske observans eller sociale status." (Zuleta \& Burkal 2017: 22)
\end{abstract}

Trods betegnelsen indeholder hadtale ikke nødvendigvis hadefuld sprogbrug i form af eksempelvis skældsord (Geyer 2018: 24; Jaki \& De Smedt 2019: 6). I stedet fremhæves det ofte at hadtale fremmer had, og evt. også diskrimination og vold mod medlemmer af den ramte gruppe (Baider et al. 2017; American Library Association 2017; Posselt 2017). Det ses som en effekt af bl.a. de sproglige udtryk der skaber et skel mellem 'os' og 'dem', og derudover beskriver de-gruppen med dehumaniserende og stereotypicerende betegnelser, $\mathrm{fx}$ ved at kategorisere referenterne som dyr eller sygdomme, eller ved at tilskrive gruppen negative egenskaber som lav

3 Jeg vil gerne takke Carlsbergfondet for at have finansieret dette projekt (CF17-0997). Projektbeskrivelsen findes her: https://nors.ku.dk/forskning/projekter/truslers-sprog-og-genre/ og den offentlige del af vores trusselskorpus findes her: https://alf.hum.ku.dk/korp/\#?lang=en\&cqp=\% $\% 5 \mathrm{~B} \% 5 \mathrm{D}$. 
intelligens eller voldsparathed (ECRI 2016; Posselt 2017; Geyer 2018; Jaki \& De Smedt 2019; Mendelsohn mfl. 2020).

Et væsentligt kriterium for at en ytring regnes for hadtale, er således at den er begrundet i offerets tilhørsforhold til en bestemt gruppe, og ofte en gruppe der i forvejen diskrimineres (Baider et al. 2017: 3). Herhjemme ses hadtale ofte rettet mod borgere med anden etnisk baggrund end dansk. Men hadefulde og truende udsagn kan naturligvis også ramme andre. I det analyserede datamateriale findes fx en række beskeder rettet mod politikerne på Christiansborg, se (2) og (3).

(2) Hvis Regeringen ikke gør noget,SÅ SKAL VI ÆGTE DANSKERE SGU NOK SLAGTE DE SJAKALER!!!

(3) Kan de ik også lige skyde alle inden på Christiansborg.. De er da for syge i hovedet... Smid en fucking bombe..

På samme måde ser man at medlemmer af en samfundsmajoritet, nemlig hvide, bliver kategoriseret som ofre for hadtale i FBI's kriminalitetsstatistik ("anti-white bias"; FBI Uniform Crime Reporting Program 2011).

Hadtale bliver ofte beskrevet som sproglig vold, dvs. overgreb der udføres med sproget alene og ikke kræver yderligere følgehandlinger (Matsuda et al. 1993 taler om 'assaultive speech'; Butler 2013 om 'injurious speech'). På lignende vis er en af truslens centrale funktioner at give den ene part magt over den anden gennem intimidering (Gales 2010: 2, 15; Christensen \& Bojsen-Møller 2019). Skræmmefunktionen indgår som et væsentligt kriterium for strafbarhed i straffelovens trusselsparagraf, $§ 266$ :

\section{§ 266.}

Den, som på en måde, der er egnet til hos nogen at fremkalde alvorlig frygt for eget eller andres liv, helbred eller velfærd, truer med at foretage en strafbar handling, straffes med bøde eller fængsel indtil 2 år.

Det er derfor ikke overraskende at trusler regnes for en af flere mulige måder at udføre hadtale på (jf. definitionen fra Institut for Menneskerettigheder). Det fremgår også af den danske straffelovs $§ 266 \mathrm{~b}$, den såkaldte racismeparagraf:

\section{§ 266 b.}

Den, der offentligt eller med forsæt til udbredelse i en videre kreds fremsætter udtalelse eller anden meddelelse, ved hvilken en gruppe 
af personer trues, forhånes eller nedværdiges på grund af sin race, hudfarve, nationale eller etniske oprindelse, tro eller seksuelle orientering, straffes med bøde eller fængsel indtil 2 år.

Tilskyndelse til vold indgår til gengæld ikke i lovbestemmelsen, selvom Rådet for Den Europæiske Union i en rammebeslutning fra 2008 om bekæmpelse af hadtale og voldelige hadforbrydelser anbefaler unionens medlemslande at kriminalisere bl.a.:

"all conduct publicly inciting to violence or hatred directed against a group of persons or a member of such a group defined by reference to race, colour, religion, descent or national or ethnic origin" (Rådet for Den Europæiske Union 2008: 2)

En principiel forskel på trusler og tilskyndelse til vold er at trusler som regel formidles direkte til offeret, eller på en måde så de kan komme til offerets kendskab (Nielsen, Elholm \& Jakobsen 2017: 530-532), mens tilskyndelse formidles til dem der tænkes at kunne udføre den skadelige handling. Hadtale rummer som overbegreb begge, idet den netop ikke kun sker i kommunikation direkte til offeret eller offergruppen, men også i kommunikation til en antaget vi-gruppe, dvs. dem der formodes at dele afsenders synspunkter på offergruppen (se fx Waltman \& Haas 2011: 34; Geyer 2018: 28-29).

\section{Data: Anmeld Had}

Datamaterialet for denne undersøgelse kommer fra det nu nedlagte Center for Forebyggelse af Eksklusion (CFE), en dansk NGO der arbejdede for at modvirke systemisk eksklusion af især etniske minoriteter i Danmark. I perioden 2015-2019 kørte CFE projektet "Anmeld Had" der havde som fokus at dokumentere tilfælde af hadtale og hadforbrydelser. Til det formål oprettede centret en hjemmeside med en online formular hvor brugere kunne anmelde sådanne hændelser ${ }^{4}$. Hver udfyldt formular blev vurderet af frivillige jurister, og potentielt kriminelle handlinger sendt videre til politiet. Anmeldelsesformularen indeholdt felter til gerningspersonens navn (hvis det var tilgængeligt), hvad den formodede motivation bag handlingen var,

4 Hjemmesiden havde adressen www.cfe.dk/anmeld-had/anmeld/, men er ikke længere aktiv. 
hvilken gruppe offeret tilhørte, hvor handlingen blev begået, hvilken dato det skete, og - afgørende for sproglig analyse - muligheden for at uploade et (skærm)billede af hændelsen.

Det samlede datasæt består af 1058 af disse formularer fra perioden februar 2015 til februar 2019, hvoraf en del er irrelevante eller ubrugelige for sproglig forskning, fx ved ikke at dokumentere hændelsen, fordi det er en genganger, eller fordi hændelsen kun var fysisk og ikke sproglig. Vi har i trusselsprojektet ikke foretaget fuldstændige optællinger af det samlede materiale, men isoleret interessen til ytringer der omhandler en fremtidig handling eller hændelse der kunne være skadelig for nogen. Det selektionskriterium resulterede i 346 beskeder som er dem der indgår i analyserne i denne artikel 5 .

Langt hovedparten af disse 346 beskeder (94\%) viste sig at være kommentarer på Facebook, ofte på sider tilhørende nyhedsleverandører som DR, TV2 og Ekstrabladet, eller i en lukket Facebookgruppe. Ud fra navnene på disse lukkede (og nu slettede) grupper fremgår det tydeligt at det især er muslimer og indvandrere der lægges for had i dette materiale:

- JA TIL FRIHED - NEJ TIL ISLAM

- $\quad$ NEJ - til kriminelle indvandrere og islam

- Nej til indvandring i Danmark

- Fedrelandet

I et speciale baseret på samme materiale kategoriserer Fröling (2020) kun 91 beskeder som egentlige trusler, og hun understreger at der selv blandt disse findes grænsetilfælde, fx når afsender indlejrer den omtalte skadeshandling under et propositionelt holdningsverbum som håbe (se afsnit 5.1).

\section{Skadespradikater}

Ifølge mine optællinger indeholder materialet i alt 394 skadesprædikater med meget store frekvensforskelle. Det hyppigste skadesprædikat er skyde med 65 forekomster, og så sker der et voldsomt fald til det næsthyppigste som er brande med 15 forekomster (se figur 1).

5 Jeg takker projektets ene studentermedhjælper, Anna Olsen, for gennemgang af det samlede materiale samt transskription og notering af metadata for de 346 beskeder (plus én der var på engelsk og er udeladt herfra). 


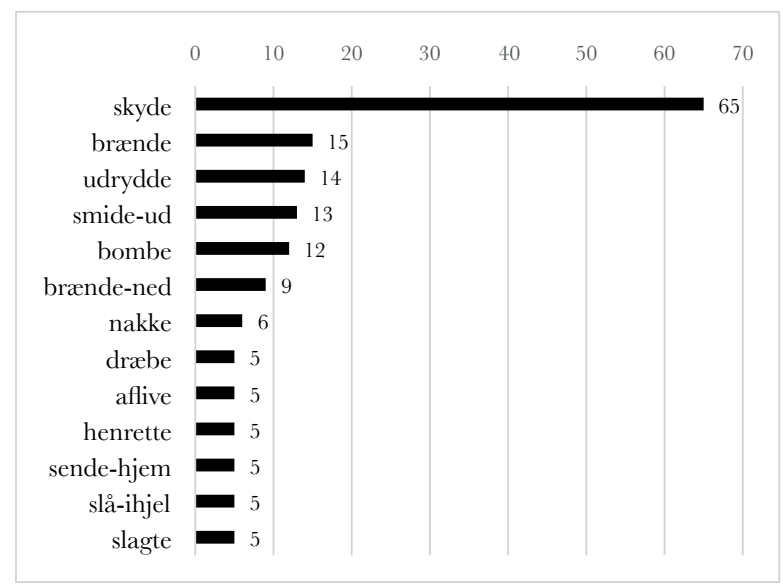

Figur 1. Skadespredikater der forekommer mindst fem gange i de 346 beskeder

Tabel 1 herunder illustrerer variationen i skadesprædikater ved på den ene side at skelne mellem forskellige former for skade og på den anden side om de leksikalske prædikaters valens kræver en agent eller ej (tabellen er inspireret af Muschalik 2018: kap. 4.4). De agentive prædikater er transitive og de ikke-agentive er intransitive. Nogle af de intransitive prædikater profilerer situationen sådan at der ikke er nogen agent, fx det inkausative verbum dø (Hansen \& Heltoft 2011: 1273). Her må jeg understrege at der i dette materiale helt konsekvent hentydes til ikke-naturlig og ikke-selvforskyldt død. Så selvom disse verbers valens ikke forudsætter en agent, kan man sige at de pragmatiske omstændigheder gør.

\begin{tabular}{|c|c|c|}
\hline & Agentive (transitive) & Ikke-agentive (intransitive) \\
\hline Drab & $\begin{array}{l}\text { aflive, drukne, drabe, halshugge, henrette, } \\
\text { honge, likvidere, nakke, slagte, slå ihjel, } \\
\text { udrydde... }\end{array}$ & $\begin{array}{l}\text { drukne, do, ende som } \mathrm{fo}_{0} \text { Cox }{ }^{6} \text {, falde dod } \\
\text { om, ryge i helvede, sulte ihjel ... }\end{array}$ \\
\hline Vold & $\begin{array}{l}\text { banke, kore ind } i, \text { pine, skyde, smadre, } \\
\text { svinebinde, voldtage ... }\end{array}$ & $\begin{array}{l}\text { få tesk/et par på hovedet/ motorsmadder } \\
\text {... }\end{array}$ \\
\hline Tvang & $\begin{array}{l}\text { fange, internere, låse inde, sende hjem, } \\
\text { smide ud... }\end{array}$ & have en returbillet hjem, stå i gabestok... \\
\hline Ødelæggelse & $\begin{array}{l}\text { brende (ned), bombe, vande med griseblod } \\
\text { (om moskéer) ... }\end{array}$ & $\begin{array}{l}\text { få samme skabne (som moskéer ramt af } \\
\text { påsatte brande i Sverige) ... }\end{array}$ \\
\hline
\end{tabular}

Tabel 1. Agentive og ikke-agentive skadespredikater/-konstruktioner

6 Jo Cox var et britisk parlamentsmedlem der blev myrdet ved skud og knivstikkeri i 2016. 
Materialet indeholder også skadesprædikater der angiver en situation som alt andet lige kan ventes at lede op til udførelsen af en skadeshandling/aktivitet $^{7}$, som det ses i fx (4) nedenfor.

(4) og knalder du mig finder jeg og vi andre dig så kan du børste tænder med en håndgranat .. er du med .. STIKKER DRENG ..

Også prædikater som i sig selv ikke nødvendigvis refererer til voldelige eller dødelige hændelser, har jeg regnet for skadesprædikater når konteksten tilsiger det, som i (5) og (6).

(5) Alle muslimer skulle bare proppes ind i en stor raket. Som så skulle flyves direkte op i solen.

(6) Tag ham og stil 4 andre på række...derved skal der kun bruges 1 kugle!!!

Blandt de 394 skadesprædikater er der endelig en mindre gruppe der ikke udtrykkes verbalt. Dem analyserer jeg ikke nærmere i denne artikel, men gengiver blot nogle illustrative eksempler der viser at ansvaret for udførelsen af disse handlinger efterlades helt åbent. Det er dels etfeltshelheder som i (7)-(8), dels sætningsemner som i (9)-(11).

(7) Oplagt chance for et contra terror angreb.

(8) perfekt mål for en lille bombe.

(9) I ovnene med dem..

(10) Frem med våbene.

(11) UD MED SÅDANT ET PAR ABEKATTE

Ifølge Hansen \& Heltoft (2011: 1623-1624) er det præpositionen eller retningsadverbialet der har rollen som prædikat i sætningsemner idet de forudsætter en aktivitet eller bevægelse. Med præpositionalet placeret først, som I, Frem og UD i (9)-(11), bliver den illokutionære kraft direktiv (Hansen \& Heltoft 2011: 148-149). Jeg vender tilbage til andre former for direktive sproghandlinger i materialet i afsnit 5.4.

7 Jf. også Christensen \& Bojsen-Møller 2019 og Christensen 2019 om hvordan indirekte trusler kan fremsættes med henvisning til en af de forberedende betingelser, fx at man har evnen eller midlerne til at skade modtageren. 


\section{Relation mellem afsender og agent hhv. modtager og patient}

Som allerede nævnt har sproghandlingen trussel afsender som agent og typisk også modtager som patient for den fremtidige skadeshandling. Prototypiske, direkte trusler realiserer agenten som pronominalt subjekt og patienten som objekt i en simpel aktiv sætning, som det fremgik af eksempel (1), her gentaget som (12).

(12) Jesper Bang din lille svans, jeg gennemtæsker dit ansigt

Selvom fokus i de efterfølgende analyser er på realiseringen af agenten for skadesprædikaterne, noterer jeg konsekvent om modtager er det tiltænkte offer eller ej. Det skyldes at tilskyndelser som tidligere nævnt ikke er henvendt til offeret, men til dem der kunne tænkes at udføre handlingen. Da der i materialet fra Anmeld Had ofte kun er meget begrænsede oplysninger om konteksten, tager jeg udgangspunkt i beskedernes sproglige udformning for at vurdere om de er henvendt til det tiltænkte offer eller til andre. Det vil sige at hvis der fx bruges et proprium som henvendelsesform (som Jesper Bang i eksempel (12)) eller et andenpersonspronomen i rollen som patient for en skadeshandling (fx Hvis jeg måtte ville jeg springe en bombe mod jer), har jeg kodet beskeden som henvendt til offeret.

\subsection{Agent $=$ afsender; Offer $=$ modtager}

Det er kun et mindretal af beskederne der er henvendt direkte til det tiltænkte offer, nemlig 42 af de 346 beskeder. Blandt disse realiserer godt halvdelen afsender som agent i subjektsposition og med et førstepersonspronomen, i sjældne tilfælde i form af subjektellipse, jf. tabel 2.

\begin{tabular}{lrr}
\hline Agent & N & \% \\
\hline 1 sg & 13 & 57 \\
$1 \mathrm{pl}$ & 7 & 30 \\
1 sg, 1pl & 1 & 4 \\
subjektellipse & 2 & 9 \\
\hline I alt & 42 & 100 \\
\hline
\end{tabular}

Tabel 2. Agentrealiseringer $i$ beskeder henvendt til offeret 
Som forventet er der en del trusler i denne undergruppe. Det er især tydeligt når skadesprædikatet står som det finitte verbal i en simpel, aktiv sætning i præsens. Offeret kan være modtager selv (13), en bredere gruppe som modtageren tilhører (14), eller en af modtagers nærmeste (15).

(13) Henrik Lind og du knækker ikke nogle, jeg knækket [tolkes som slåfejl for præsens knekker; TKC] dine tænder og derefter ta [tager; TKG] vi dine klamme danske knogler

(14) Vi indfører langsomt sharia over hele landet og vi brænder alt hvad I har.

(15) jeg knepper din mor din fucking søn af en hund

Eksemplerne i (13)-(15) er alle direkte trusler, men der findes også indirekte trusler hvor man må fortolke afsender som agent for en underforstået skadeshandling. Det ses fx i (16) der indholdsmæssigt ligner den velkendte trusselstype "vi ved hvor du bor" ved at invitere til den inferens at afsender har tilstrækkeligt kendskab til modtager til at kunne opsøge hende ${ }^{8}$.

(16) Pas på Inger. Vi har dit navn og grimme ansigt nu. Pas på hvad du skriver fremover i denne sag.

Blandt denne undergruppe findes desuden en del med en mere kompliceret syntaks. I disse konstruktioner er skadesprædikatet indlejret under andre verber, enten som en infinitiv (17) eller en ledsætning (18).

\section{:: JEG TAGER GERNE TO ÅR I SPJÆLLET BARE FOR AT NAKKE DIG ::}

(18) i er årsagen til jeg efterhånden håber vi får en borgerkrig så vi kan udrydde jer og jeres afkom

Disse indlejringer skaber ikke bare en mere kompleks syntaktisk struktur, men indskyder også en indholdsmæssig afstand mellem afsender og udførelsen af skadeshandlingen. Selvom afsender er agenten for de beskrevne

8 Trusselstypen vi ved hoor du bor kan henføres til en af de forberedende betingelser for en trussel, nemlig at man i skal være i stand til at udføre en skadelig handling. Det kræver at man kan få adgang til offeret, hvilket igen kræver at man ved hvor offeret befinder sig (jf. Searle 1979; Christensen \& Bojsen-Møller 2019; Christensen 2019). 
skadeshandlinger og modtager er offeret, er det ikke lige så åbenlyst at ytringerne udgør trusler som i eksempel (12)-(16). Jeg diskuterer eksemplerne et ad gangen herunder.

I (17) ser vi en form for hensigtserklæring (jeg tager gerne ...) der kan relateres til kommissivers oprigtighedsbetingelse, dvs. at afsender har til hensigt at udføre den fremtidige handling (se de to lidt forskellige bud på vellykkethedsbetingelser for trusler i Christensen \& Bojsen-Møller 2019 og Christensen 2019). Sprogfilosoffer har gennem længere tid diskuteret hvorvidt trusler forpligter afsenderen til at udføre den fremtidige handling ligesom det gælder for løfter (se fx Salgoeiro 2010). Der er fx næppe nogen ofre der vil beklage sig over at en skadelig handling som de var blevet truet med, ikke blev ført ud i livet, hvilket de med rette kunne hvis et løfte ikke blev opfyldt. Ikke desto mindre fungerer truslen bedst hvis det virker overbevisende at afsenderen kunne finde på at udføre handlingen.

Men hvad så hvis handlingen ikke forekommer realistisk? Det er hvad vi ser i eksempel (18) hvor skadesprædikatet refererer til den ultimative ødelæggelse af modtagergruppen (udrydde) som led i en forestillet fremtidig borgerkrig. Det er ikke noget afsender selv kan foranledige, og dermed lever ytringen ikke op til en af de forberedende betingelser for trusler, nemlig at afsender skal være i stand til at udføre skadeshandlingen (Christensen \& Bojsen-Møller 2019). Der er dog flere grunde til at antage at vellykkethedsbetingelserne for trusler også på dette punkt er anderledes end dem for løfter. Forberedelsesbetingelsen drejer sig ikke så meget om hvorvidt afsender er i stand til at udføre den omtalte handling, men snarere om at få modtager til at tro på at man kunne udføre enten den eller noget lignende. Det er således ifølge Fraser (1998: 162) ikke nødvendigt at den omtalte handling faktisk er skadelig for modtager, bare modtager indser at intentionen er at skade ${ }^{9}$. Det afgørende er altså at man (dvs. modtageren og andre der læser beskeden) ud fra ytringen kan slutte sig til at afsender har en skadelig hensigt, og at ytringen fremsættes med det formål at skræmme modtageren netop gennem denne erkendelse (Fraser 1998: 161, 171; Christensen 2019: 119, 122).

Eksempel (18) illustrerer endnu en problemstilling der fremkommer af

9 Fraser (1998: 161) illustrerer pointen således: Udsagnet "Jeg giver dig roser til din fødselsdag" kan fungere som en trussel hvis det er ytret til en man tror er dødeligt allergisk over for roser. Det gælder også selvom modtageren faktisk ikke er allergisk over for roser, hvis vedkommende bare ved at afsender tror det. 
dette datasæt, nemlig at den fremtidige skadeshandling er dækket ind under et håb. Verbet håbe peger i sig selv på en emotiv sproghandling, dvs. et udtryk for afsenders holdninger eller følelser. I dette tilfælde er det der håbes på, dog noget afsender selv fremstilles som agent for, dvs. udrydde-handlingen. Når afsender præsenterer udryddelsen af modtagergruppen som noget ønskværdigt, og som noget han gerne selv vil bidrage til, udtrykker han en klar skadelig hensigt. Der kan dermed principielt godt være tale om en indirekte trussel i eksempel (18). Samtidig er det dog min vurdering at holdningsverbet håbe bidrager til at gøre ytringen mindre truende end fx (17), fordi verbet nedtoner afsenders tilslutning til den skadelige hensigt.

Som den sidste type jeg vil nævne i denne undergruppe, er det man kunne kalde en slags ikke-trusler. Dem finder vi i irreale konstruktioner som i (19)-(20).

(19) Vær glad for jeg ikke kan losse dig retur til det land dine rødder stammer fra, for så var du der allerede ...

(20) Hvis jeg måtte ville jeg springe en bombe mod jer...

I (19) kombineres den imperative opfordring Var glad for med en negeret og modaliseret ledsætning: [at] jeg ikke kan losse dig retur. Den efterfølgende hovedsætning, der indledes med for, har en underforstået betingelse: for [hvis jeg gjorde det] så var du der allerede. Præteritumsformen var understreger at den ønskede skadeshandling er kontrafaktisk (dvs. irreal).

I (20) ser vi en betingelsesledsætning med et deontisk (tilladelsesorienteret) måtte i præteritum, der lader hovedsætningens volitive (Hansen \& Heltoft 201 1: 59) ville jeg springe en bombe fremstå kontrafaktisk. Selvom den beskrevne skadeshandling bliver præsenteret som kontrafaktisk, er budskabet dog stadig at afsenderne af (19) og (20) gerne ville udføre en skadelig handling mod modtager hvis de kunne, og dermed udtrykker de en intention om skade som kan virke truende, også selvom formuleringerne negererer selve truslen.

I de næste undergrupper ser jeg på beskeder der er henvendt til andre end offeret for skadeshandlingen. Det gælder størstedelen af beskederne i dette materiale, nemlig $87 \%$.

\subsection{Agent $=$ afsender, Offer $=$ tredje person}

Også i beskeder der er henvendt til andre end offeret, kan afsender fremstille sig selv om agenten for den skadelige handling i form af forstepersonspronomener. Derudover finder vi her anvendelse af det upersonlige pronomen man, jf. tabel 3 . 


\begin{tabular}{lrr}
\hline Agent & $\mathbf{N}$ & $\mathbf{\%}$ \\
\hline $1 \mathrm{sg}$ & 16 & 27 \\
$1 \mathrm{pl}$ & 33 & 55 \\
$1 \mathrm{sg}$, 1pl & 1 & 2 \\
subjektellipse & 6 & 10 \\
man & 4 & 7 \\
\hline I alt & 60 & 100 \\
\hline
\end{tabular}

Tabel 3. Agentrealiseringer $i$ beskeder henvendt til andre end offeret

Der ses en væsentlig lavere andel agenter i 1 sg her end ved de beskeder der var henvendt direkte til offeret $(27 \% \bmod 57 \%$ i tabel 2$)$. Her er til gengæld relativt flere agenter i $1 \mathrm{pl}$, under subjektellipse og derudover med man. Alle er grammatiske midler der peger mindre entydigt på afsender selv som agenten for den skadelige handling, end 1sg gør. Det afspejler rimeligvis at beskederne er stilet til en gruppe der antages at være sympatisk indstillede over for afsenders budskab, det der også kaldes en in-group (fx Geyer 2018: 29).

En del af ytringerne i denne undergruppe fremstiller desuden den skadelige handling som noget der er normativt påkrævet af agenterne, typisk udtrykt gennem modalverber som i (21) og (22).

(21) Vi burde storme lordtet... RAMBO Kom ind. Kalder Rambo..

(22) Vi skal på gaden med tanks og hver mand med maskingevær.. Enhver rød radikal skal have et skud hvis de prøver på noget rod..

Disse konstruktioner følger det transitive mønster fra den foregående gruppe med agenten realiseret som subjekt. Men et 'vi' kan også realiseres som objekt for lade i imperativ. Eksempel (23)-(24) har kohortativ betydning og er altså opfordringer til fælles handling (Hansen \& Heltoft 2011: 1423).

(23) Lad os give dem Dailog med en AK47

(24) Ja lad os bombe ders byggegrunde med døde grise og vande hele grunden med grisse blod så bygger de ikke der

Eftersom der er tale om indbyrdes opfordringer, er der både et kommissivt og et direktivt aspekt i lad os-konstruktionerne: Afsender præsenterer sig 
selv som villig til at udføre handlingen hvis nogle andre i modtagergruppen også er med.

Der ligger sproghandlingsmæssigt en interessant diskussion i om en ytring kan være en trussel når den ikke er henvendt til offeret. Harmon (2008) indfører begrebet "pledge to harm" ${ }^{10}$ om tilfælde hvor psykiatriske patienter under terapi afslører ønsker eller intentioner om at skade andre mennesker, typisk nogle af deres nærmeste. Her kan den professionelle part være juridisk forpligtet til at advare det potentielle offer om at deres sikkerhed er truet (Harmon 2008: 30). Harmon argumenterer selv for at der ikke er tale om en trussel når ytringen ikke er henvendt til offeret (2008: 34), ikke mindst fordi den faktiske modtager, terapeuten, ikke bliver skræmt i forhold til sit eget liv eller helbred. Omvendt kategoriserer Hurt (2021) udtrykte hensigter om skade mod tredjeperson som trusler. Han undersøger primært beskeder om planlagte masseskyderier der er formidlet på sociale medier, dvs. på gerningsmændenes personlige blogs, i forskellige chatrum og på Twitter. Der er dermed en forskel i rækkevidden af ytringerne i forhold til Harmons studie, og derfor også i hvem der kan få kendskab til dem. I sidste ende kan et potentielt offer være blandt modtagergruppen for disse beskeder. Det kan gøre en forskel for om de rent juridisk kan tælle som trusler eller ej, i hvert fald i dansk retspleje der tillader at en trussel kan være formidlet til tredjeperson hvis denne tredjeperson kan tænkes at bringe truslen videre til offeret (Nielsen, Elholm og Jakobsen 2017: 530-532). Her er det dog snarere platformen, dvs. Facebook, end en tredjeperson der muliggør at offeret kan få kendskab til truslen.

\subsection{Agent ukendt; Offer = tredje person}

En velkendt måde at skjule agenten for en handling er at bruge en passivkonstruktion med agensstrygning (Løj \& Wille 1985). Der er tre passivtyper repræsenteret i dette datasæt med den fleksiviske $s$-passiv som den absolut dominerende, se tabel 4. Ingen af passiverne har agenten udtrykt (hvilket kan ske i form af et frit valensled, såsom Pengene blev overfort af banken; Hansen \& Heltoft 2011: 632).

10 Den direkte oversættelse af engelsk pledge er 'tilsagn' eller 'løfte', men det passer ikke godt på den kontekst Harmon (2008) beskriver. Der er snarere tale om en tilkendegivelse af en skadelig hensigt mod andre. 


\begin{tabular}{lrr}
\hline Passiver & $\mathbf{N}$ & $\mathbf{\%}$ \\
\hline S-passiv & 51 & 88 \\
Blive-passiv & 6 & 10 \\
Fä-passiv & 1 & 2 \\
\hline I alt & 67 & 100 \\
\hline
\end{tabular}

Tabel 4. Passivtyper i materialet

$S$-passiverne forekommer hovedsageligt under modalverbet skulle. Det giver ifølge Hansen \& Heltoft (2011: 788-789) dels ophav til instruksbetydning, dels til pligtbetydning. Det skyldes kombinationen af skulles semantik som 'intentionel nødvendighed' og s-passivens som en non-subjektiv, dvs. ikke afsenderbundet, form (Hansen \& Heltoft 2011: 787; Heltoft \& Falster Jakobsen 1996). Kodningen viser ikke om det er afsender eller nogen eller noget uden for afsender der er modalfaktor, dvs. 'sætter' nødvendigheden (Hansen \& Heltoft 2011: 771). Skulle $+s$-passiv kan fx angive en norm for hvad der vil være det rigtige at gøre - af nogle andre end afsender selv. Se eksempel (25).

(25) Der er ikke en eneste reel flygtning imellem alle de ISLAMISKE STORMTROPPER. De skal nakkes !!!

Selvom konstruktionerne med skulle + s-passiv grammatisk set peger på betydninger som norm og pligt, lader der også til at være tale om et stærkt ønske hos afsenderen, bl.a. signaleret ved brugen af udråbstegn. Den 'norm' der hentydes til, er desuden i direkte modstrid med hvad flertallet i et åbent, demokratisk samfund orienterer sig imod. Dette sammenstød mellem normer ses ekstra tydeligt når der kræves iværksættelse af handlinger der ville kræve ændring af de nuværende love, se (26).

(26) Moskèerne skal jævnes med jorden! Imamerne skal udvises. Islam skal forbydes. Ikke som religion men som politisk voldsideologi.

S-passiver forekommer også under modalverberne burde og måtte med lignende normsammenstød som ved skulle, men dem kommer jeg ikke nærmere ind på i denne artikel.

De relativt sjældne blive-passiver forekommer til gengæld slet ikke under 
modalverber. I overensstemmelse med deres kodning som subjektiv form finder man flere tilfælde af hvad man kunne kalde afsenders 'onde håb’ (27).

(27) Håber satme de bliver fanget og pines resten af livet...

Her har kombinationen af håbe og agensstrygningen den effekt at ytringen ikke kan læses som en trussel. Der er dog også blive-passiver hvor agensstrygningen ikke udelukker at afsender er agenten for skadeshandlingen. Det gælder fx (28) hvor blive-passiven hverken er styret af et modalverbum eller er indlejret under et nonrealt holdningsverbum som håbe eller ønske.

$$
\begin{aligned}
& \text { dine børn bliver slagted } \\
& \text { Vent og se }
\end{aligned}
$$

Denne besked kan enten læses som et ondt løfte, og dermed en trussel som afsender er (med)ansvarlig for, eller mindre inkriminerende som en 'ond forudsigelse'. Det er ikke åbenlyst en advarsel, for advarsler forudsætter at afsender vil modtager det godt (Fraser 1998: 165-166), og det er der ikke meget der tyder på når man læser beskeden i sin helhed:

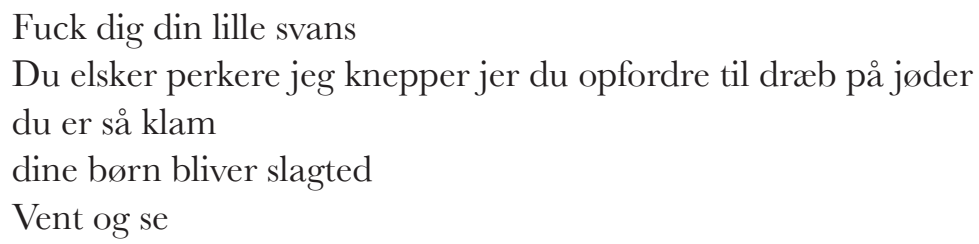

Givet resten af beskeden i (29) kan man argumentere for at afsender selv påtager sig ansvaret for udførelsen af skadeshandlingen, og at passivvendingen primært er begrundet informationsstrukturelt (Løj \& Wille 1985), dvs. for at tage udgangspunkt i modtagers børn.

Materialet indeholder også en del inagentive $f a$-konstruktioner (Hansen \& Heltoft 201 1: 1306-1307). Her refererer subjektet fortsat til offeret, ligesom i passiverne, men agenten for 'overdragelsen' er udeladt, se (30).

(30) Den turist, venstredrejede psykopat, burde få dummeslag

Det sker dog også i disse konstruktioner at man inferentielt kan placere ansvaret for skadeshandlingen hos afsender, som i (31). 
(31) Hun får et par på hovet når jeg møder hende, møg luder.

Fællestrækket for ytringerne i denne undergruppe er at agenten for den fremtidige skade ikke realiseres grammatisk, selvom man syntaktisk eller pragmatisk kan regne ud at der må være en agent. En oplagt grund til at udelade agenten er at trusler om grov vold er strafbare. Passiver og inagentive $f a$-konstruktioner kan dermed bruges til at så tvivl om afsenders involvering i udførelsen af den skadelige handling (jf. også begrebet 'plausible deniability'; Pinker, Nowak og Lee 2008).

Samtidig gælder der det for denne undergruppe at de heller ikke er henvendt til offeret, men snarere til et virtuelt diskursfællesskab af ligesindede. Ikke desto mindre foregår meget af denne kommunikation på offentligt tilgængelige platforme, og afsenderne må derfor vente at der er andre end deres ligesindede der læser med, herunder potentielt også folk der hører til i offergruppen. De vil så på én gang kunne genkende sig selv som del af offergruppen, og se sig beskrevet i tredjeperson, som nogen der står uden for fællesskabet (jf. begrebet alienering eller othering; Geyer 2018: 28-29; Lumsden \& Harmer 2019).

Selvom afsender altså ikke præsenterer sig selv som agent for den fremtidige skade mod offeret, kan beskederne godt skræmme de sekundære modtagere (dem man med Goffman 1981 kunne kalde ikke-ratificerede deltagere).

Den sidste undergruppe jeg vil gennemgå, omfatter grammatiske konstruktioner der entydigt flytter ansvaret for skadeshandlingen over på andre end afsender selv. Det gælder ikke mindst ved brug af verber i imperativ, som udgør knap halvdelen af de finitte verber jeg har kategoriseret som skadesprædikater ${ }^{11}$.

\subsection{Agent $=$ andre; modtager $=$ andre}

I modsætning til hvad der gælder for passiver med agensstrygning, regner man det generelt ikke for uklart hvem der skal udføre handlingen $\mathrm{i}$ en imperativ: det er altid modtageren ${ }^{12}$. Til gengæld medfører Facebooks karakter

11 Materialet indeholder også eksempler på ytringer hvor agenten realiseres som et tredjepersonspronomen, fx Jeg håber de gasser dem, eller et nominalsyntagme, fx Måske på tide med nogle dødspatruljer der ku nakke alle danske forreder-svin og stikkere!!!!! Det drejer sig kun om 16 tilfælde i alt, og jeg kommer af pladshensyn ikke nærmere ind på dem her.

12 Der findes også imperativer der ikke forudsætter en handlende agent, som $\mathrm{fx}$ sov godt, men de er ikke repræsenteret i dette materiale. 
som mange-til-mange-kommunikation at modtager, og dermed agenten, $\mathrm{i}$ praksis er svær at identificere. Det er bare ikke afsender selv.

Det er påfaldende hvor hyppigt imperativ forekommer i dette materiale. Godt $40 \%$ af de finitte skadesprædikater står således i imperativ. Tendensen til at skyde og brende er de hyppigste skadesprædikater (jf. figur 1) bæres af imperativformerne, hvilket afspejles i at det 9.-hyppigste bigram (to-ordskombination) er skyd dem ${ }^{13}$.

Offeret repræsenteres hovedsageligt som en vagt afgrænset gruppe med enten pronomener i 3. person flertal (32)-(33), eller en nedsættende term (34).

(32) Omring dem, brug strømpistoler og tåregas.

(33) Brænd brænd og atter brænd deres lort, en gang for alle !!

(34) smid lordet ud

Imperativer udtrykker afsenders ønske om at en given handling skal blive udført og fungerer hovedsageligt som direktive sproghandlinger (Christensen 2009; Hansen \& Heltoft 2011: 732). Det er derfor rimeligt at overveje om disse imperativer (såvel som andre direktiver i materialet) kan tælle som tilskyndelse til forbrydelse.

I næste afsnit anvender jeg Peter Harms Larsens (1973) analyse af straffelovens tilskyndelsesparagraf til at vurdere om imperativerne (og de andre direktive sproghandlinger) i dette materiale rent principielt lever op til paragraffens kriterier.

\section{Offentlig tilskyndelse til forbrydelse}

Peter Harms Larsen skrev i 1973 en detaljeret analyse af straffelovens generelle tilskyndelsesparagraf. Bestemmelsen lyder som følger:

\section{§ 136.}

Den, som uden derved at have forskyldt højere straf offentlig tilskynder til forbrydelse, straffes med bøde eller fængsel indtil 4 år.

Larsen fokuserer på bestemmelsens kriterier om offentlighed, forbrydelse og så naturligvis hvad det vil sige at tilskynde nogen.

13 Til sammenligning er de tre hyppigste bigrammer det er, til at og $u d$ af (det sidste illustrerer igen at materialet er hadtale rettet mod indvandrere og efterkommere som ønskes $u d$ af Danmark). 
Hvad den leksikalske betydning af ordet offentlig angår, argumenterer han for at bestemmelsen må sigte på folks adgang til en meddelelse, og ikke om den er udsendt af en offentlig myndighed (jf. også betydningsvarianterne i DDO). Overført på materialet fra Anmeld Had kan man umiddelbart konstatere at i hvert fald de kommentarer der er skrevet på de åbne sider på Facebook, er formidlet offentligt. Også de lukkede Facebookgrupper kan ifølge dansk retspraksis betragtes som offentlige, for så vidt som mange har adgang, og der sjældent sker en egentlig frasortering af medlemmer (Nielsen, Elholm \& Jakobsen 2017: 150).

Hvad der tæller som forbrydelse i denne paragraf, svarer til hvad man finder ved trusselsparagraffen, nemlig at der skal være tale om en vis grovhed. Det kriterium er også opfyldt af de fleste af beskederne her, som det fremgår af gennemgangen af skadesprædikaterne i afsnit 4. Enkelte falder uden for dette kriterium, $\mathrm{fx}$ hvis de omtaler skadeshandlinger der ikke defineres som grov vold (fx at banke, at give et spark bagi o.lign.), og andre er så vagt beskrevet at de vil kunne afvises i retten på baggrund af princippet om at tvivlen skal komme tiltalte til gode ( $\mathrm{f}$ finde og ordne resten).

Spørgsmålet om beskederne sproghandlingsmæssigt tæller som tilskyndelser, er betinget af om de kan læses som direktiver. Rent grammatisk lever såvel imperativiske sætninger som sætningsemner med foranstillet præpositional op til det krav (Harms Larsen 1973: 20; Hansen \& Heltoft 201 1: 148-149). Det samme gælder ytringer der kan læses som indbyrdes opfordringer til en større vi-gruppe (ikke bare lad os-konstruktionerne, men også de deontisk modaliserede forestillinger om den 'rigtige' måde at håndtere situationen på: vi skulle, vi burde, samt de mere løst formulerede forslag af typen hvad med at/om vi...).

Pragmatisk set er der dog udfordringer i forhold til den forberedende betingelse der gælder for direktiver, at modtager skal være i stand til udføre handlingen (Searle 1979: 44). Det er langt fra alle beskederne der angiver skadeshandlinger der kan udføres i noget realistisk scenarie. Tværtimod er der en del der synes formuleret med henblik på chokeffekten snarere end som noget der med rimelighed kan forventes udført, se fx (35).

(35) Snit dem i halsen og put en lille sprængladning i og kør dem så til grænsen... og fortæl... kommer du tættere på den danske grænse end $10 \mathrm{~km}$ så... booooooom...

Her kan man indvende at det ligesom ved truslerne ikke nødvendigvis er afgørende om den beskrevne skadeshandling er realistisk, men snarere 
opfordringen til at udføre skade i det hele taget. Ifølge Kommenteret straffelov tager tilskyndelsesparagraffen, § 136 stk. 1, sigte på tilfælde hvor "den forbrydelse, der tilskyndes til, ikke er således konkretiseret, at strafansvar kan pålægges" (Nielsen, Elholm \& Jakobsen 2017: 149). Selvom fx forbrydelsen i eksempel (35) er særdeles konkret beskrevet, er det muligt at fortolke bestemmelsen sådan at det er tilskyndelse til forbrydelse generelt, og ikke en specifikt beskrevet forbrydelse, der kriminaliseres i straffeloven (se lignende eksempler fra sagen mod Said Mansour, "boghandleren fra Brønshøj" i Marott 2019).

\section{Diskussion}

Som nævnt er en potentiel begrundelse for at udelade agenten for en omtalt skadeshandling, at man vil distancere sig selv fra handlingen, fx for at undgå retsforfølgelse for trusler. Men selvom man ikke via sin formulering tager ansvar for skadeshandlingens udførelse, er man stadig ansvarlig for den ytring man producerer. Selvom ytringsfriheden er en grundlovsfæstet ret i Danmark, er den begrænset til at ske "under ansvar for domstolene", som det hedder i Grundlovens $\S 77$ :

\section{$\S 77$.}

Enhver er berettiget til på tryk, i skrift og tale at offentliggøre sine tanker, dog under ansvar for domstolene. Censur og andre forebyggende forholdsregler kan ingensinde påny indføres.

Med andre ord er kriminaliserede sproghandlinger ikke beskyttet af ytringsfriheden. Tilsvarende præciserer Den Europæiske Menneskerettighedskonventions artikel 10, stk. 2, at ytringsfriheden bl.a. begrænses af hensyn til andres rettigheder:

\section{Artikel 10. Ytringsfrihed}

1. Enhver har ret til ytringsfrihed. Denne ret omfatter meningsfrihed og frihed til at give eller modtage meddelelser eller tanker, uden indblanding fra offentlig myndighed og uden hensyn til grænser. ... 2. Da udøvelsen af disse frihedsrettigheder medfører pligter og ansvar, kan den underkastes sådanne formelle bestemmelser, betingelser, restriktioner eller straffebestemmelser, som er foreskrevet ved lov og er nødvendige i et demokratisk samfund af hensyn til den nationale sikkerhed, territorial integritet eller offentlig sikkerhed, for at 
forebygge uorden eller forbrydelse, for at beskytte sundheden eller sædeligheden, for at beskytte andres gode navn og rygte eller rettigheder, for at forhindre udspredelse af fortrolige oplysninger eller for at sikre domsmagtens autoritet og upartiskhed.

Det er især punktet om at "beskytte andres gode navn og rygte eller rettigheder" der er relevant når sagen drejer sig om hadtale, herunder også om trusler og tilskyndelse til vold. I juridisk øjemed burde det derfor være strafbart at ytre sig som det sker i datasættet fra Anmeld Had.

Årsagen til at vi ikke ser hyppig retsforfølgelse af sådanne ytringer, er formentlig dels at det ville være meget omkostningstungt at føre så mange sager, dels at vi herhjemme kun sjældent ser voldelige overfald der kan knyttes til tilskyndelser til og billigelse af vold mod hadtaleofre. Der er i hvert fald to ting at holde sig for øje her: For det første er der ikke noget krav i loven om at trusler eller tilskyndelser faktisk følges op af handling, eller bare af planer om handling (tværtimod ville begge lede til selvstændige sigtelser i en straffesag). Alene det at udsige truslen eller tilskyndelsen er altså strafbart. For det andet er der mange studier der peger på en sammenhæng mellem hadtale og voldelige hadforbrydelser, men ikke nødvendigvis udført af nogen som afsenderne har en personlig relation til.

Studier fra USA og Tyskland har således vist en statistisk korrelation mellem stigninger i hadtale på sociale medier og voldelige overfald mod offergrupperne (Müller \& Schwarz 2019a, 2019b). Brugt som politisk propaganda kan hadtalens dehumanisering af en modstander endda gøde jorden for folkedrab som det er set i fx Nazityskland, Rwanda og Serbien (Klemperer 2013; Schabas 2000; Dojčinović 2020).

Jeg vil understrege at jeg finder det tvivlsomt om afsenderne bag de danske hadebeskeder analyseret i denne artikel ville ønske sig at noget så grumt og grusomt skete mod dem de omtaler. Når fx journalister har opsøgt folk der skriver sådan på nettet, er de som regel forbløffede over at nogen tog det som en trussel. Ikke desto mindre er det vigtigt at vi som samfund diskuterer hvilke former for kommunikation vi vil acceptere i det offentlige rum. Uanset den faktiske intention bag ytringerne er hadtale sårende og psykisk nedbrydende for ofrene (Matsuda mfl. 1993; Butler 2013). Som borgere kan vi være med til at påpege når andre går for langt, og tydeligt markere at det er uacceptabelt. Som lingvister kan vi belyse hvordan hadtale og relaterede kriminelle sproghandlinger virker, og på den måde være med til at skabe opmærksomhed om problemet. 


\section{Om forfatteren}

Tanya Karoli Christensen, ph.d., Institut for Nordiske Studier og Sprogvidenskab på Københavns Universitet.

\section{Litteratur}

American Library Association (2017): Hate Speech and Hate Crime. http:// www.ala.org/advocacy/intfreedom/hate (lokaliseret 25. april 2021)

Baider, F. H., S. Assimakopoulos \& S.L. Millar (2017): Hate speech in the EU and the CONTACT project. Online Hate Speech in the European Union: A Discourse-Analytic Perspective, Cham: Springer, 1-6. doi:10.1007/978-3319-72604-5

Butler, J. (2013): Excitable Speech: A Politics of the Performative. Taylor and Francis. doi:10.4324/9780203948682

Christensen, T.K. (2009): Tag nu bare økomælken. Om imperativ og modalpartikler i dansk. Dramatikken i grammatikken. Festskrift til Lars Heltoft. Roskilde Universitet, 51-67.

Christensen, T.K. (2019): Indirect threats as an illegal speech act. Ken Ramshøj, Henrik Jørgensen, Johanna Wood (red.) The Sign of the V: Papers in Honour of Sten Vikner. Aarhus: AU Library Scholarly Publishing Services, 113-130. doi:10.7146/aul.348.92

Christensen, T.K. \& M. Bojsen-Møller (2019): Sproglige virkemidler i indirekte trusler. I: Y. Goldshtein, I. Schoonderbeek Hansen \& T. Hougaard (red.). 17. Møde om Udforskningen af Dansk Sprog. Århus: Aarhus Universitet, 207-226.

Coulthard, M., A. Johnson \& D. Wright (2017): An Introduction to Forensic Linguistics. Language in Evidence. 2. udg. London: Routledge.

Dojcinovic, P. (2020): In the Mind of the Crime: Proving the Mens Rea of Genocidal Intent in the Words of Ratko Mladić and Other Members of the Joint Criminal Enterprise. I: P. Dojcinovic (red.). Propaganda and International Criminal Law: From Cognition to Criminality. Routledge, 1-28. https://ssrn.com/abstract=3500023 (lokaliseret 25. april 2021)

ECRI, European Commission against Racism and Intolerance (2016): ECRI General Policy Recommendation no. 15 on Combating Hate Speech. Strasbourg: The Council of Europe.

FBI Uniform Crime Reporting Program (2011): Hate Crime Statistics. https://ucr.fbi.gov/hate-crime/2011/narratives/victims_final.pdf (lokaliseret 25. april 2021). 
Fraser, B. (1998): Threatening revisited. Forensic Linguistics 5, 159-173. doi:10.1558/sll.1998.5.2.159.

Fröling, A.C.H. (2020): Afsenderansvar i sprogligt fremsatte trusler - en narsproglig analyse. Speciale. Dansk, Københavns Universitet.

Geyer, K. (2018): Hadetalens grammatik. Ny forskning i grammatik 25, 16-33. doi:10.7146/nfg.v26i25.109300

Goffman, E. (1981): Forms of talk. University of Pennsylvania Press.

Heltoft, L. \& L.F. Jakobsen (1996): Danish passives and subject positions as a mood system. I: E. Engberg-Pedersen, M. Fortescue, P. Harder, L. Heltoft \& L.F. Jakobsen (red.). Content, Expression and Structure: Studies in Danish Functional Grammar (Vol. 29). John Benjamins Publishing, 199234. doi:10.1075/slcs.29.08hel

Jaki, S. \& T. De Smedt (2019): Right-wing German hate speech on Twitter: Analysis and automatic detection. arXiv preprint. arXiv: 1910.07518.

Klemperer, V. (2013): LTI - Lingua Tertii Imperii. Det Tredje Riges sprog - en filologs notesbog. København: Tekst og tale.

Larsen, P.H. (1973): Om "offentligt at tilskynde til forbrydelse". En studie i forholdet mellem sprog, jura og politik. NyS - Nydanske Sprogstudier 5, 5-39. doi:10.7146/nys.v5i5.10339

Leonard, R.A., J.E.R. Ford \& T.K. Christensen (2017): Forensic linguistics: Applying the science of linguistics to issues of the law. Hofstra Law Review 45, 501-517.

Lumsden, K. \& E. Harmer (red.) (2019): Online Othering - Exploring Digital Violence and Discrimination on the Web. New York: Springer. doi:10.1007/9783-030-12633-9

Løj, M., \& N.E. Wille (1985): Kan vi undvære passiv? eller: Kan passiv virkelig undværes? En undersøgelse af passivformernes grammatik, stilistik og pragmatik. NyS-Nydanske Sprogstudier 15, 5-42. doi:10.7146/ nys.v15i15.13333

Marott, R.L. (2019): Strafbare ytringer. Sproghandlinger ijuridisk kontekst. Upubliceret speciale i dansk. København: Københavns Universitet.

Matsuda, M.J., G.R. Lawrence III, R. Delgado \& K. Williams Crenshaw (red.) (1993): Words that Wound: Critical Race Theory. Assaultive Speech, and the First Amendment. Boulder: Westview Press.

Mendelsohn J., Y. Tsvetkov Yulia \& D. Jurafsky (2020): A Framework for the Computational Linguistic Analysis of Dehumanization. Frontiers in Artificial Intelligence 3.55 s. https://www.frontiersin.org/article/10.3389/ frai.2020.00055 (lokaliseret 25. april 2021). doi:10.3389/frai.2020.00055 
Müller, K. \& C. Schwarz (2019a): Fanning the flames of hate: Social media and hate crime. SSRN 3082972. doi:10.1093/jeea/jvaa045

Müller, K. \& C. Schwarz (2019b): From hashtag to hate crime: Twitter and anti-minority sentiment. SSRN 3149103. http://dx.doi.org/10.2139/ ssrn.3149103

Nielsen, G.T., T. Elholm, M.N. Jakobsen (2017): Kommenteret Straffelov: Speciel del. 11. udg. København: Jurist- og Økonomforbundets Forlag.

Posselt, G. (2017): Can hatred speak? On the linguistic dimensions of hate crime. Linguistik Online 82(3), 5-25. doi:10.13092/lo.82.3712

Rådet for Den Europæiske Union (2008): Council Framework Decision 2008/913/JHA of 28 November 2008 on combating certain forms and expressions of racism and xenophobia by means of criminal law. Official fournal of the European Union L 328/55. http:/ / eur-lex.europa. eu/LexUriServ/LexUriServ.do?uri=OJ:L:2008:328:0055:0058:en:P DF (lokaliseret 25. april 2021).

Schabas, W.A. (2000): Hate speech in Rwanda: The road to genocide. Mc Gill Law fournal 46(1), 141-172.

Shuy, R.W. (1993): Language crimes: The use and abuse of language evidence in the courtroom. Cambridge: Blackwell.

Searle, J.R. (1979): Indirect speech acts. Expression and Meaning: Studies in the Theory of Speech Acts. Cambridge: Cambridge University Press, 30-57. doi:10.1017/CBO9780511609213.004

Solan, L. \& P.M. Tiersma (2005): Speaking of crime, the language of criminal justice. Chicago: University of Chicago Press. doi:10.7208/ chicago/9780226767871.001.0001

Waltman, M., \& Haas, J. (2011): The Communication of Hate. Peter Lang. doi:10.3726/978-1-4539-0046-8

Zuleta, L. \& R. Burkal (red.) (2017): Hadefulde ytringer $i$ den offentlige debat. København: Institut for Menneskerettigheder. 